\title{
Cartografía de una memoria: Space Invaders de Nona Fernández o el pasado narrado en clave de juego
}

\author{
A Memory's Cartography: Nona Fernandez's Space Invaders \\ or the Past Narrated Under a Game Code \\ Cartografia de uma memória: Space Invaders de Nona \\ Fernández ou o passado narrado em chave de jogo
}

\section{Macarena Urzúa}

UNIVERSIDAD FINIS TERRAE, CHILE

Profesora de la Escuela de Literatura de la Facultad de Comunicaciones y Humanidades de la Universidad Finis Terrae en Santiago de Chile. Ph.D. en Literatura Hispanoamericana por Rutgers University, The State University of New Jersey. Su investigación se ha especializado tanto en la poesía chilena y latinoamericana del siglo XX como en el cine y la crónica chilenos, con énfasis en teorías de la memoria y el paisaje. Ha publicado numerosos artículos académicos sobre poesía chilena de la postdictadura y la ciudad, así como también textos sobre crónica y cine chileno en revistas especializadas del campo literario y cultural como Revista Iberoamericana, Chasqui y Revista Chilena de Literatura. Correo electrónico: murzuaopazo@gmail.com

Artículo de reflexión

Documento accesible en línea desde la siguiente dirección: http://revistas.javeriana.edu.co 


\section{Resumen}

En la novela de Fernández Space

Invaders (2013) se observa, a través de la metáfora extraída de un juego de Atari, la perspectiva única que permite dibujar otra cartografía de la ciudad: la de la memoria postdictatorial. La constante alusión al videojuego de Arcade Space Invaders, popularizado en los años ochenta, opera en la novela como una alternativa para narrar el pasado y escribir el relato de quienes crecieron durante la dictadura. El presente trabajo intenta dar cuenta del lugar que ocupa el juego y de su rol en el modo de narrar el pasado reciente. Space Invaders opera así como una alegoría de una parte de la infancia, a la que se vuelve, a partir de la ficción.

Palabras clave: memoria; juego; infancia; Nona Fernández; literatura chilena

\section{Abstract}

In Fernandez' novel, Space Invaders (2013), we can see, through the metaphor extracted from an Atari game, a unique perspective that allows for the drawing of a different cartography of the city: one of the post-dictatorial memory. The constant allusion to the arcade videogame 'Space Invaders', popularized in the eighties, operates in the novel as an alternative to narrate the past and write the story of those who grew up during the dictatorship. This work tries to provide an account of the place the game occupies and its role in the way of narrating the recent past. Space Invaders operates in this way as an allegory of a part of the childhood, to which it returns, this time from fiction.

Keywords: memory; game; childhood; Nona Fernández; Chilean literature

\section{Resumo}

No romance de Fernández Space Invaders (2013) observa-se, através da metáfora extraída de um jogo de Atari, a perspectiva única que permite debuxar outra cartografia da cidade: a da memória pós-ditatorial. A constante alusão ao videojogo de Arcade Space Invaders, popularizado na década de oitenta, opera no romance como alternativa para narrar o passado e escrever o relato daqueles que cresceram durante a ditadura. $\mathrm{O}$ presente trabalho visa dar conta do lugar ocupado pelo jogo e do seu papel no modo de narrar o passado recente. Space Invaders opera assim como alegoria de uma parte da meninice, para a que se volta, a partir da ficção.

Palavras-chave: memória; jogo; meninice; Nona Fernández; literatura chilena

RECIBIDO: 22 DE DICIEMBRE DE 2015. ACEPTADO: 14 DE FEBRERO DE 2016. DISPONIBLE EN LÍNEA: 29 DE DICIEMBRE DE 2017

\section{Cómo citar este artículo:}

Urzúa, Macarena. "Cartografía de una memoria: Space Invaders de Nona Fernández o el pasado narrado en clave de juego". Cuadernos de Literatura 21.42 (2017): 302-318 . https://doi.org/10.11144/Javeriana.cl21-42.cmsi 
"Pero, como el sueño, el arte está más allá de la memoria; apela al pensamiento puro como facultad de las esencias. Lo que el arte nos permite recobrar es el tiempo tal como se ha enrollado en la esencia, tal como nace en el mundo envuelto de la esencia, idéntica a la eternidad".

DELEUZE, PROUST Y LOS SIGNOS

"Santiago de Chile. Año 80. En un liceo del barrio Avenida Matta, una niña de diez años entra de la mano de su papá" (13). Esta escena de la primera vida es visualmente reconocible por varios de nosotros: nos imaginamos ese ir al colegio en los ochenta, cantar el himno nacional con las estrofas agregadas, izar la bandera, etc. Nona Fernández, en su última novela Space Invaders (2013), hace alusión al juego de Atari popularizado en los ochenta, para hablar de la memoria y de un relato de los hijos de la dictadura. Me interesa entonces dar cuenta del modo de narrar este pasado y del lugar del juego en ese relato de Nona Fernández, en el que el narrador vuelve a la infancia de los ochenta y del Liceo. De esta manera la experiencia narrada, junto con la forma en la que se vuelve al pasado, ocurre a partir del relato de la ficción. La primera escena, que abarca las líneas iniciales de la nouvelle, es una imagen en la que varios de los niños que crecieron y fueron a la escuela en los años ochenta en Chile, pueden reconocerse. Imágenes tales como: formar la fila, cantar el Himno Nacional los días lunes, izar la bandera, y comenzar cada semana así, son porciones de una memoria colectiva que es revisitada aquí.

En Space Invaders se mezclan la historia y la ficción. La novela comienza en el año 80, luego de la aprobación de la nueva Constitución, con una niña que entra al Liceo de la mano de su padre. En ese contexto aparecen hechos históricos concretos como el asesinato de tres profesores durante la dictadura de Pinochet - Guerrero, Parada y Nattino-, el llamado caso Degollados y la muerte de los hermanos Vergara Toledo en Villa Francia, entre otros. El narrador recuerda todos esos hechos históricos junto a sus ex compañeros de colegio; se vuelve al pasado: "Han pasado años. Demasiados años. Nuestros colchones, lo mismo que nuestras vidas, se han desperdigado en la ciudad hasta desconectarse unos de otros. ¿Qué ha sido de cada uno?" (16). Esta imagen de los colchones que habitan la ciudad que no ha sido nombrada como espacio en su especificidad, va delimitando una cartografía afectiva y emotiva a la que solo se vuelve en los sueños. Los colchones, desperdigados como sitios de memoria itinerantes, operan a nivel simbólico como ese vínculo con la memoria histórica reciente. 
El epígrafe de La cámara oscura de Georges Perec puede dar pistas sobre cómo entrar a esa memoria: "Estoy sometido a este sueño: sé que no es más que un sueño, pero no puedo escapar de él" (s.p.). El sueño como un recurso aparece constantemente en el libro de Fernández. Este puede ser leído como una cámara oscura con la que se revelan recuerdos, imágenes y registros del pasado captados por ella; lo expuesto develará aquello que ha sido registrado y que pasa afuera del relato enmarcado.

"Space Invaders" fue el nombre de un popular videojuego de Arcade que fue inventado por Toshihiro Nishikado y que cumplió, justamente en 2013, 35 años: la edad de varios autores y lectores que vivieron su infancia y parte de su juventud durante la dictadura militar. En este texto de Nona Fernández, el juego se halla inserto como parte de la narración en la novela; funciona como una alegoría en la que caben tanto la historia como los recuerdos que pertenecen a la esfera de una memoria individual.

En Maus: A Survivor's Tale (1980-1991), Art Spiegelman relata, a partir de imágenes y texto, la historia de su padre, sobreviviente de los campos de concentración nazis. Por medio de viñetas se va narrando, en parte, la memoria del holocausto y la vida de la familia Spiegelman antes y después de la guerra, desde la experiencia directa del padre de Art. En este caso, el hijo, Art Spiegelman, desde su rol de narrador/autor/dibujante, emplea en este dibujo de la memoria, la alegoría del animal, en este caso de ratas y gatos, para representar a judíos y nazis, respectivamente. Según Linda Hutcheon, este cómic da cuenta también de que en el postmodernismo las fronteras otrora existentes entre narración de ficción, historia y biografía, son cada vez más difusas (5). Maus es también analizado por el historiador James Young en el artículo "Art Spiegelman's 'Maus' and the After-Images of History". Young analiza la forma en que este cómic incorpora diversas memorias: la memoria mítica del pasado, la historiografía y la autobiografía. El mismo Spiegelman dice que quiso relatar cómo le había sido contada esa historia, en sus palabras: recrear el storytelling de la memoria de su padre, que él transformó en un cómic; en un cuento que, con dibujos, arma una lectura para contar una parte de la historia traumática de su padre y de las víctimas del holocausto. Asimismo, también es una historia para hablar de su presente y de la relación con su padre. ${ }^{1}$

1 La crítica y académica Gabriel Schwab, en su libro Haunting legacies. Violent Histories and Transgenerational Trauma, alude a la forma en que Marianne Hirsch, en Family Frames: Photography, Narrative and Postmemory, se refiere al trauma transgeneracional en Mauss. 
"In Spiegelman's own words, 'Maus is not what happened in the past, but rather what the son understands of the father's story[']" (Young, capítulo I s.p.). De manera similar, en la novela Space Invaders nos enfrentamos a aquello que se comprende de la historia; a los residuos de un gran relato de los hechos ocurridos en los ochenta en Chile, contado y mirado desde la perspectiva de la infancia, a la que se vuelve como al pasado, solo desde la ficción. ${ }^{2}$ Esa historia y memoria en el caso de Spiegelman, son narradas con cierta distancia: la del hijo dibujante que busca una forma de relatar la vida pasada y traumática del padre, al mismo tiempo que quiere recrear la forma en que este le contó esa historia (storytelling).

En la novela de Nona Fernández, la memoria y el pasado de la infancia en la dictadura, conforman una experiencia que tiene como mediadora, por un lado, a su narradora, a ratos narrador, que juega en Atari el juego "Space Invaders". En ambos relatos, es la experiencia la que se halla mediada por un dibujo o un juego que constituyen las formas de narrar.

Sin hacer comparaciones entre una historia y otra, creo que el usar distintas formas de contar un relato, utilizando alegorías o metáforas como las que envuelve la recurrencia a un animal o un juego, habla de esa frontera borrosa que hay entre la historia con mayúscula, la biografía, la memoria individual, la memoria colectiva y, también, la narración. En Space Invaders el dispositivo es aprovechado para entrar en el pasado y en la narración es el juego de video, que asimismo opera como una alegoría de los años ochenta en el contexto de la dictadura militar. Este aparato implica un lenguaje, una temporalidad y unas reglas que se circunscriben al tiempo y al lugar que tiene el momento retratado, en este caso, los del videojuego, hasta que

Este es visto como un texto paradigmático y generativo de una estética que transcurre en las intersecciones que se originan entre la historia privada y la pública. Para Schwab las historias familiares o los traumas heredados siempre están llenos de silencios: "Such silences and secrets inevitably affect aesthetic forms and modes of production and representation in secondgeneration narratives about the legacies of violent histories" ("Introduction" 13). Esta idea de cómo los silencios y secretos afectan la forma estética de apropiarse de ciertas herencias de memorias, creo, puede ser leída en relación con ciertas narraciones chilenas de los últimos años, y es denominada la narrativa de los hijos.

2 El escritor argentino César Aira señala, en su ensayo "Lo incomprensible", la idea de que la literatura que nos gusta muchas veces nos atrae porque no la entendemos del todo. Es decir, se trata de una ficción en la que parece que podemos seguir al narrador y escritor en su búsqueda: "Todo escritor va hacia la claridad perfecta, pero el camino es un rodeo por lo incomprensible" (s.p.). 
aparece en la pantalla GAME OVER. Asimismo Space Invaders se narra en un sitio como el colegio durante los 80 (del que se sale una vez para una manifestación), en el que también se juega, siendo este un espacio único de libertad, dentro de la atmósfera represiva que se vivía en esos años. El juego de Atari también ocurre en el espacio interestelar, lo que opera entonces como metáfora, por un lado, de lo desconocido y, por otro, de lo que aparece y desaparece en la pantalla, y que está destinado a terminar. Se lo delimita así como el tiempo de la infancia, aquí dentro de la invasión o la vigilancia que pueden representar estos extraterrestres, que bien pueden referirse a la policía, los militares, los inspectores, etc. Los desconocidos, los otros, pueden, tal como en el juego, "atacarte".

En cierto punto la memoria se vuelve inarticulable; por tanto, en la novela, para volver al pasado, se recurre al juego como alegoría que entrega en sí misma una historia y un lenguaje en particular. "Las balas verdes fosforescentes de los cañones terrícolas avanzaban rápidas por la pantalla hasta alcanzar a algún alienígena [...] Y cuando moría el último, cuando la pantalla quedaba pelada, otro ejército de alienígenas aparecía desde el cielo dispuesto a seguir batallando" (Fernández 24).

\section{Sobre el juego: narrar desde su memoria}

En Profanaciones, Giorgio Agamben dedica una sección de su texto a analizar el tema del juego en relación con el rito y lo sagrado:

La mayor parte de los juegos que conocemos deriva de antiguas ceremonias sagradas, de rituales y de prácticas adivinatorias que pertenecían tiempo atrás a la esfera estrictamente religiosa. La ronda fue en su origen un rito matrimonial; jugar con la pelota reproduce la lucha de los dioses por la posesión del sol; los juegos de azar derivan de prácticas oraculares; el trompo y el tablero de ajedrez eran instrumentos de adivinación. Analizando esta relación entre juego y rito, Emile Benveniste ha mostrado que el juego no sólo proviene de la esfera de lo sagrado, sino que representa de algún modo su inversión. (100)

En la novela, el juego no solo se desprende de esa potencialidad del rito, sino que profana, en este caso, la vida, las vidas y la invasión alienígena representadas en Space Invaders. Los otros se muestran como una alegoría de lo que invade fuera de la infancia y termina por afectarla. Para Agamben este tipo de juegos apuntan a construir otra relación con ese rito inicial que la práctica de jugar tuvo alguna vez: "En este sentido, los juegos televisivos de masas forman parte de una nueva liturgia, secularizan una intención 
inconscientemente religiosa. Restituir el juego a su vocación puramente profana es una tarea política" (101), o acaso religiosa, agregamos, en cuanto a tener y compartir una experiencia común; un modo de enfrentarse al mundo desde la vida y la muerte a la que se expone el jugador frente al juego de video. Juego en el cual el episodio se repite y quien juega es siempre una posible víctima, siempre lista para el sacrificio. Agamben finalmente alude al carácter episódico del juego, ya que después de este se debe retomar la vida normal (111).

Sin embargo, en la novela, el juego de los invasores del espacio se constituye como uno de carácter episódico: se repite. No obstante, aquí se halla ausente la condición de que una vez terminado el juego se vuelva a la normalidad, ya que durante la dictadura nunca se vive en un régimen de cotidianeidad normal.

Decía el juego "beware the invasion" y mientras uno disparaba desde naves a estas caritas o a los invasores, uno iba perdiendo vidas. El historiador Johan Huizinga, quien ha estudiado la relación existente entre el juego y el hombre en Homo ludens, analiza el origen del juego, remontándose a la antigüedad, periodo en que este estuvo siempre relacionado con la lucha, el peligro, así como también con el deber; de ahí la idea y el dicho popular de hablar de aquello que "está en juego" (60). Esta relación se encontraría, para Huizinga, desde la etimología de la palabra; de esta manera "[e]l juego es lucha y la lucha es juego" (60).

El narrador en la novela de Nona Fernández usa esta alegoría del juego de Atari, que se centra en unos invasores que quieren llegar a la tierra, para hablar de la memoria de la infancia de los años ochenta. Así, el juego continúa a lo largo del texto:

[...] un marcianito del space invaders, un pulpo con brazos de varias formas que juega este juego a oscuras que está a punto de terminar. La luz se enciende de golpe y el inspector nos mira desde la puerta. Todos estamos muy bien ordenados, los hombres al lado derecho, las mujeres al izquierdo. Algunos leen un libro. (47)

Llama la atención el evidente intertexto con el poema "La pieza oscura", quizás uno de los más conocidos del poeta chileno Enrique Lihn. Esto ya lo señaló Jaime Pinos en el epílogo de Space Invaders con su ensayo titulado "Aprender a despertar" (83). Así lo vemos al leer los siguientes versos del poema: 
¿Qué será de los niños que fuimos? Alguien se precipitó a encender la luz, más rápido que el pensamiento de las personas mayores.

Se nos buscaba ya en el interior de la casa, en las inmediaciones del molino: la pieza oscura como el claro de un bosque.

Pero siempre hubo tiempo para ganárselo a los sempiternos cazadores de niños. Cuando ellos entraron al comedor, allí estábamos los ángeles sentados a la mesa ojeando nuestras revistas ilustradas - los hombres a un extremo, las mujeres al otro- en un orden perfecto, anterior a la sangre. (Lihn, "La pieza oscura" 17)

En Lugar incómodo Matías Ayala analiza la poesía de Lihn y nota que hay en ella ciertos lugares propios de la infancia, como la pieza oscura o el patio del Liceo Alemán presente en el poema "Nunca salí del horroroso Chile". Estos son espacios que refieren a la identidad y a la formación; a aquello que nos determina: ambos se enmarcan en la definición de ser "poema de formación o iniciación" (83). El autor cita los siguientes versos finales de "La pieza oscura": "Pero una parte de mí no ha girado al compás de la rueda, a favor / de la corriente. / Nada es bastante real para un fantasma. Soy en parte ese niño / que cae de rodillas" (17). Ayala afirma que, tanto este poema como "Nunca salí del horroroso Chile" hablan de la represión de la educación y del patio del colegio como sinécdoque de Chile, de la nación:

No es gratuito que el otro poema más famoso y antologado de Lihn, "Nunca salí del horroroso Chile", también lidie con aquello que los psicólogos llaman "socialización": la internalización de las normas y valores sociales de la familia, la escuela, grupos de pares y medios de comunicación. En este caso la represiva nación chilena - alusión quizás al momento dictatorial- se vuelve análoga al patio del colegio de la infancia; o al contrario, el patio escolar persiste de forma espectral en el presente. "Nunca salí del horroroso Chile / nunca salí del habla que el Liceo Alemán/ me infligió en sus dos patios como un regimiento["]. (86)

No se puede salir tampoco de esa memoria, de la celebración del 21 de mayo, del héroe Prat, ni de los recuerdos de Estrella González, la amiga de Riquelme, Zúñiga, Maldonado y Donoso, que un día deja de ir al colegio: una niña a la que se la ha muerto el hermano y nadie sabe cómo. Se enteran de esto mientras hacen un trabajo sobre la Guerra del Pacífico. Guerra de la que más tarde hay una representación: el recuerdo del barco hecho de papel 
lustre, los bigotes hechos con corcho quemado: "Muchachos, la contienda es desigual [...] Nunca se ha arriado nuestra bandera ante el enemigo [...] Mientras yo viva, esa bandera flameará en su lugar [...] Soy un héroe. Todos los años, para el 21 de mayo, me toca serlo" (30). El más recordado de nuestros héroes es visto aquí como parte de otro relato que entra en el juego: aquel de la memoria histórica que es impuesta, en el contexto del lugar y el espacio de la infancia; un artificio o casi un relato de ficción que no tiene mucho sentido cuando somos niños. ${ }^{3}$

James Young se ha referido a cómo la memoria se traspasa de una generación a otra, particularmente en el caso de Maus. De esta misma manera sostengo que el tratamiento de la memoria reciente, presente en la novela de Fernández, transcurre mientras los personajes no son afectados directamente por el contexto, pero está ahí; lo oyen, lo intuyen, y asimismo el narrador es también testigo de lo que se sabrá más tarde en Space Invaders. La represión; el caso de los profesores comunistas Parada y Nattino degollados; el asesinato de Tucapel Jiménez; las manifestaciones en contra de Pinochet, entre otros sucesos que son tratados en capítulos segmentados, que operan como aquellos fragmentos de memoria que cualquier narrativa, ya sea histórica biográfica o autobiográfica, intenta unir. Capítulos fragmentados que son, también, parte del juego Space Invaders; solo se puede tener tres vidas y si pierdes se acaba: aparece en la pantalla GAME OVER. Así aparecer también, repetidamente el juego del Chevy rojo en el patio del colegio, y con esa rutina de juegos surge la posibilidad de vivir otro mundo dentro de ese mundo represivo de los adultos, en donde lo que manda es el silencio. El narrador afirma: "Somos la gran pieza del juego pero todavía no sabemos cuál" (53). Walter Benjamin en "La literatura infantil" analiza el juego de los niños y sus efectos al crear este otro mundo, dentro del "real":

Es cierto que el juego siempre libera. Rodeados de un mundo de gigantes, los niños al jugar crean uno propio, más pequeño; el hombre, brusca y amenazadoramente acorralado por la realidad, hace desaparecer lo terrorífico en esa imagen reducida.

Antes del triunfo de Arturo Prat, otros héroes eran objeto de veneración y de conmemoración, tales como el mapuche Colipí, héroe de guerra en la Guerra contra la Confederación Perúboliviana, y la sargento Candelaria, chilena, dueña de una cantina en Perú y que se transformó en cantinera del ejército chileno, participando en la Batalla de Yungay. Sin embargo, es interesante notar cómo cambia la memoria colectiva al prácticamente olvidar estos otros dos personajes históricos y dejar solo a Prat como el héroe por antonomasia. Para mayor referencia sobre Prat y los héroes chilenos, véase el volumen de William Sater, La imagen heroica en Chile. Arturo Prat, un santo secular. 
Así le resta importancia a una existencia insoportable y ello ha contribuido en gran manera al creciente interés que han despertado desde el fin de la guerra los juegos y libros infantiles. (82)

Esta afirmación de Benjamin adquiere coherencia al analizar el juego como dispositivo de memoria en esta novela, en donde podemos señalar que, más que liberar, se crea otro mundo en ese otro mundo de los grandes, para así poder ir, desde lo oficial de la historia que puede ser contada en una imagen, hasta la figura que emerge del extraterrestre que invade la tierra. Todo juego tiene la característica de la repetición, sostiene Benjamin; más bien, opera desde una ley de la repetición: condición que también se observa en el juego de video. Sin embargo, aparentemente ninguna repetición sería aquí idéntica a la anterior.

Desde esta idea podemos leer la siguiente descripción del juego en la novela:

La mano avanza rápida a la caza de algún niño extraterrestre. Los niños corren de un lado a otro, huyen asustados, pero la mano se abalanza sobre la primera espalda marciana que encuentra y a su contacto la hace explotar. El cuerpo del marcianito se desarticula en luces coloradas que desaparecen de la tele [...] La mano verde y muchas otras manos verdes, salen de un cañón terrícola a la caza de más space invaders. (54)

El enfrentarse a esa imposibilidad desde el ámbito del juego, no es sinónimo necesariamente de la banalización de la memoria, sino justamente del dar cuenta de cómo se hace ese traspaso de memoria. Los recuerdos de infancia se hallan marcados por ciertos ritmos que parecen acompasarse con aquellos juegos que fueron parte de este periodo y de la forma de percibir el tiempo. Estas memorias, a veces vacías o con espacios en blanco, pueden ser rellenadas de los ritmos de estos juegos, sus reglas, tiempos y formas de practicarlos. De esta misma manera podemos referirnos a una práctica de nuestra propia memoria que está también compuesta de fragmentos: retazos de programas de radio, lecturas de diario, imágenes y silencios. "El tiempo no es claro, todo lo confunde, revuelve los muertos, los transforma en uno, los vuelve a separar, avanza hacia atrás, retrocede al revés, gira como carrusel de feria..." (Fernández 61). O girar al compás de la rueda, o no poder hacerlo, porque se va hacia atrás como en el poema de Lihn ya citado.

"Es cierto que el juego siempre libera", sostiene Benjamin, quizás no siempre; sin embargo, el juego sí deviene en un espacio simbólico en donde 
se desarrollan estas acciones, búsquedas que hacen salirse de una realidad. El ritmo de la repetición se transforma en una característica siempre inherente al ámbito del juego. Se vuelve al pasado; a aquello que siempre será inenarrable; que sí tiene lugar en un espacio al que siempre se vuelve, la infancia: aquel recuerdo borroso que se diluye como la pantalla del juego cuando se acaba: "Ninguno tiene claro el momento exacto, pero todos recordamos que de golpe aparecieron ataúdes y funerales y coronas de flores y ya no pudimos huir de eso, porque todo se había transformado en algo así como un mal sueño" (58).

En el libro de Nona Fernández hay una elipsis sobre lo que le pasó al hermano de Estrella González, la niña que deja la escuela y que manda cartas a una de sus amigas del grupo. El juego aquí parece completar esa memoria: las vidas que se pueden tener y la muerte o el final del juego; el GAME OVER ineludible:

Santiago de Chile 1994. Luego de diez años de ocurridos los hechos, la justicia chilena entrega su fallo en primera instancia por el secuestro y homicidio de los militantes comunistas José Manuel Parada, Manuel Guerrero y Santiago Nattino [... E] En la misma pantalla televisiva en la que antes se jugaba al Space Invaders ahora aparecen los carabineros responsables de las muertes. (68)

En la pantalla de la televisión que todos ven y que sintoniza la misma imagen a un tiempo, de manera extraña nos dice el narrador: "Nuestro barco de papel empezó a hacer agua [...] No sabemos despertar" (70). Lo que "se hace agua" es la infancia; el recuerdo del que no se puede despertar, ya que todavía el pasado parece un sueño, mezclado con los juegos de la infancia.

Gilles Deleuze analiza la novela En busca del tiempo perdido de Marcel Proust a través de la memoria de los signos, vista como un dispositivo que se repite en la narrativa. Así, Deleuze define esta forma de narrar en Proust y los signos, en donde "distingue cuidadosamente dos clases de signos sensibles: las reminiscencias y los descubrimientos; las 'resurrecciones de la memoria', y las "verdades escritas con ayuda de figuras" (66). Podemos afirmar que uno de los mecanismos de narración, forjado en un intento por atrapar la memoria de la infancia a partir del juego, es hacerlo legible a través de estas figuras que contribuyen a dibujar una verdad en un texto. 
"Estrella se desarticula como un marcianito en luces coloradas. El tablero de la pantalla marca cien puntos más para el score. Ni siquiera así se rompe el record".

FERNÁNDEZ

En las últimas páginas de la novela, reaparece Estrella, quien le entrega a Zúñiga una carta que nunca le llegó. "La pantalla del televisor anuncia la programación de un nuevo día. Parte con el Himno Nacional e imágenes de todo el país de Arica a Punta Arenas" (75). La cotidianeidad de esos años en los que todo pasa por la televisión; las cadenas nacionales; los pocos programas en los únicos canales de la señal; la censura y la idea de una música de fondo con esas imágenes de Chile, son un flash back generacional en el que los niños que crecieron en la dictadura pueden reconocerse. Acto seguido, Zúñiga dice: "Despierto otra vez. No hay televisor. No hay carta. Estoy solo y he envejecido un siglo" (76). En un salto temporal, hacia el final de la novela, vuelve a aparecer el patio del colegio: se forman en filas, toman distancia, se describe el uniforme:

El último botón de la camisa abrochado, la corbata anudada, el jumper oscuro debajo de la rodilla, las calcetas azules arriba, los pantalones perfectamente planchados, la insignia del liceo zurcida en el pecho [... . Nos hemos dado cita aquí. Nos hemos despegado de nuestras sábanas y colchones repartidos por la ciudad para llegar puntuales. Como siempre el sueño nos convoca. (77-78)

En esta escena del sueño no se canta el himno nacional obligado, como al comienzo del libro; algo ha cambiado: afuera lo que se oye son las calles silenciosas. La memoria como un sueño; como lo borroso y lo oscuro en donde lo que quedan son solo imágenes. Así lo plantea también Jaime Pinos en su epílogo: "Aquí los sueños y los recuerdos son una sola cosa" (83), de manera que "[a] la vuelta de todos estos años, de toda esta desmemoria, este libro nos ayuda a comprender ese juego" (86). Sin embargo, sabemos que la lógica del juego es y fue sobrevivir solos contra ese ejército de marcianos.

Creo que esta novela, entre otros textos recientes en donde hablan los hijos, los criados y educados en la dictadura, deviene en un discurso que alude a la memoria colectiva, pero desde otro lugar: el que aún cuestiona el pasado y que intenta rellenar los fragmentos de lo vivido o escuchado. Una memoria que siempre puede volver a interpretarse y narrarse; un recuerdo del juego se transforma en narración del pasado reciente de la historia de Chile, revivido por los niños que jugaban en la escuela, y por la reaparición de la amiga Estrella. 


\section{Conclusiones}

"Esa invasión de la vida por parte del juego tiene como consecuencia inmediata una modificación y una aceleración del tiempo: 'En medio del recreo continuo y las múltiples diversiones, las horas, los días, las semanas pasaban como relámpagos'. Como era previsible, la aceleración del tiempo no deja de modificar el calendario. Siendo esencialmente ritmo, alternancia, repetición...".

Se hace inevitable pensar en estos héroes arruinados, que cada vez se vacían más de sentido, y en otras de sus representaciones en la literatura chilena contemporánea: obras como Prat (2001) de Manuela Infante, o el cómic Los viajes de Massachusetts (2001) de Rodrigo Salinas. En el libro de Salinas aparece un cómic destinado al héroe Prat, quien no ha muerto en combate, como se supone, sino que reaparece años después del combate que le diera la gloria con vida en las costas de Massachusetts. Este hecho marca una irregularidad histórica que, junto con la ironía desplegada al describir al personaje, hizo que en el momento de la entrega del premio Fondart (Fondo Nacional para el Desarrollo de las Artes), utilizado para financiar el proyecto del cómic de Prat, la Armada de Chile expresara su descontento, algo que incluso llegó a ser noticia en los periódicos nacionales — como en Las Últimas Noticias en noviembre de 2001-, una vez que se supieron los resultados del Fondo Nacional. ${ }^{4}$

Space Invaders es un juego, una novela, una historia en la que vemos otra representación más, así como también en el cómic de Salinas, en donde la historia de Arturo Prat, mil veces representada en el colegio por todos $-\mathrm{y}$

4 El titular de la portada periódico Las Últimas Noticias del 17 de noviembre de 2001 dice: "Historieta 'Los viajes de Massachusetts' sostiene que el marino fue héroe accidental. Malestar en la Armada por cómic de Arturo Prat”. La página del día 17 de noviembre de 2001 es reproducida íntegra al interior de la antología de cómics de Salinas, La calma después de la tormenta. Calm Before the Storm; el mismo Salinas señala en una nota al pie, a modo de aclaración (que tampoco aclara mucho, pero que refuerza esta ironía): "Al contrario de lo que mucha gente cree. Esta saga nunca pretendió ser polémica. Ni ofender la honra de la Armada. Esta historia trata simplemente de mi Padre. Que alguna vez quiso ser marino y no pudo tener las rodillas juntas. Por suerte" (s.p.). La ironía es lo que tiñe a la historieta, no la polémica; sin embargo, al leer ambos, el cómic y la reacción de la Armada, la única posible respuesta es la risa. Ambos hechos dan cuenta de cuán frágiles son estos discursos, los símbolos patrios que se han hecho y se han establecido como necesarios para mantener cohesionada a una "comunidad imaginada", según lo señala Benedict Anderson en su libro Imagined Communities (1991). 
repetida hasta el cansancio la arenga "No se arriará bandera ante el enemigo" y el famoso "Al abordaje, muchachos", la celebración de nuestro único héroe-, toma otro rumbo.

El Yeco, V Región (Litoral Central).
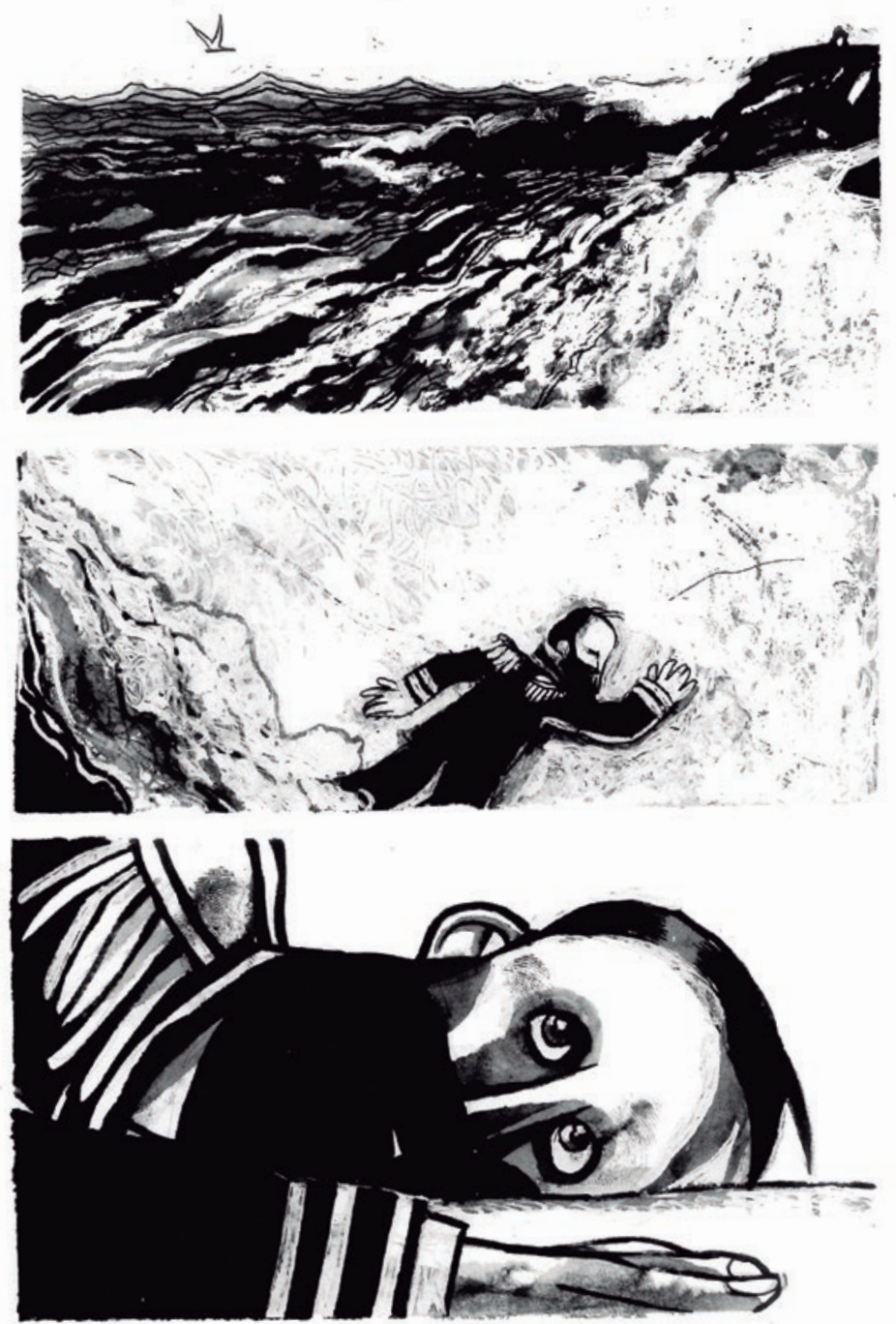

Figura 1. De Los viajes de Massachusetts de Rodrigo Salinas en La calma después de la tormenta. Calm Before the Storm (s.p.). 
El presente que aparece en Space Invaders es una dimensión temporal que se pierde en la memoria, siempre nebulosa, en donde nunca se encuentran los recuerdos, tales como esos colchones desperdigados por la ciudad descritos en la novela y que se hallan dentro de los sueños ahí descritos. Para Pinos, la generación a la que alude el texto de Fernández es inevitablemente "[u]na generación afantasmada que se hizo adulta en el hermetismo y la mudez dominantes" (84). Me parece pertinente esta idea, también, en cuanto a cómo la novela convoca voces: voces de niños de un país en el pasado. La cotidianeidad, sumergida en la violencia diaria, los funerales, ataúdes, de otro modo, el orden del liceo, la vigilancia, incluso en los juegos. Se recurre a unas imágenes; se desacralizan otras: la imagen de Prat, el relato de la dictadura con el fondo de pantalla de estos invasores del espacio. La memoria que no se puede narrar pero que se puede pensar desde el juego y el sueño; lo fragmentario, de lo que no se puede despertar del todo.

Juego: alude a aquellos recuerdos que asociamos con la diversión y la felicidad de la infancia, así como también a la cotidianeidad, que en el caso de estos niños es, también, la cotidianeidad de la dictadura en los ochenta.

Sin embargo, el juego acá es un juego solitario, en donde un jugador se enfrenta a los extraterrestres que aparecen en la pantalla. Juego en donde hay ausencia de cuerpos, de encuentro: se juega en la pantalla; lo que se ve no es lo vivido ni experimentado. El espacio interestelar, presente en la idea del juego "Space Invaders", nos remite a ese espacio que es también un territorio de todos y de nadie; un lugar en donde confluyen pasado, presente y futuro. Un territorio oscuro y luminoso en donde conviven, también, invasores e invadidos ante lo conocido y lo desconocido. ${ }^{5}$

La novela y el juego son formas de relatar lo vivido como si fuera un cuento en el que los niños juegan en una cotidianeidad siempre amenazada por estos "invasores". La memoria colectiva o común se construye, no necesariamente desde la inocencia infantil, sino desde un recuerdo que deja cicatrices hasta la actualidad de la narración. De esa manera, el juego deviene también en habla: a través de él hablan las voces de la infancia, usando este otro lenguaje que está inserto en lo cotidiano. No se sabe realmente quién habla, y es ese mismo gesto de este narrador/narradora que cruza indistintamente entre un género y otro, lo que evidencia esa dificultad de poder contar el pasado: de recrear o más bien representar esa memoria infantil. 
Gonzalo Millán, poeta chileno, sostiene que "[e]l juego del niño es la preparación para posteriores obras creativas" (18); así, podemos pensar sobre aquellos juegos solitarios, y los colectivos: aquellos en los que se compite y se comparte finalmente vida y experiencia; una suerte de preexistencia de lo que concebimos como recuerdo; la memoria que sirve para darle forma a una posterior narrativa de lo vivido. Vuelvo a "La pieza oscura de Lihn": "En el contrasentido de las manecillas del reloj se desatascó la rueda antes de girar y ni siquiera nosotros pudimos / encontrarnos a la vuelta del vértigo, cuando entramos en el tiempo" (17). La rueda que gira en el sentido de las manecillas del reloj y en su contrasentido, va al desencuentro a cruzarse en la temporalidad, al irrumpirla. La narración de Nona Fernández gira en ambos sentidos, intentando una detención del tiempo, aquello que no es escribible: volver al pasado como devolver las manecillas del reloj.

\section{Obras citadas}

Agamben, Giorgio. Infancia e historia. Destrucción de la

experiencia y origen de la historia. Trad. Silvio Mattoni. Buenos

Aires: Adriana Hidalgo editora, 2007. Impreso.

Agamben, Giorgio. Profanaciones. Buenos Aires: Adriana Hidalgo, 2005. Impreso.

Aira, César. "Lo incomprensible". El malpensante: lecturas

paradójicas 24 (agosto 1 a septiembre 15 de 2000). Web.

Anderson, Benedict. Comunidades imaginadas: reflexiones sobre el origen y la difusión

del nacionalismo. México: Fondo de Cultura Económica, 1993. Impreso.

Arroyo, Guido, ed. La poesía no es personal. Extractos de entrevistas a

Gonzalo Millán. Santiago: Alquimia editores, 2012. Impreso.

Ayala, Matías. Lugar incómodo. Santiago: Universidad Alberto Hurtado, 2010. Impreso.

Benjamin, Walter. Escritos. La literatura infantil, los niños y los jóvenes.

Buenos Aires: Ediciones Nueva Visión, 1989. Impreso.

Deleuze, Gilles. Proust y los signos. Barcelona: Anagrama, 1995. Impreso.

Fernández, Nona. Space Invaders. Santiago: Alquimia editores, 2013. Impreso.

Hirsch, Marianne. Family Frames: Photography, Narrative and Postmemory.

Cambridge: Harvard University Press, 1997. Impreso.

Huizinga, Johan. Homo ludens. Madrid: Alianza editorial, 2000. Impreso.

Hutcheon, Linda. "Literature Meets History: Counter-Discursive Comix".

Anglia: Zeitschrift fur Englische Philologie 117.1 (1999): 4-14. Web.

Infante, Manuela. Prat seguida de fuana. Santiago: Ciertopez, 2004. Impreso.

Lihn, Enrique. "La pieza oscura". La pieza oscura. Santiago:

Editorial Universitaria, 1963. 15-17. Impreso. 
Lihn, Enrique. "Nunca salí del horroroso Chile". A partir de Manhattan. Valparaíso: Ganymedes, 1979. Impreso.

Perec, Georges. La cámara oscura. Madrid: Editorial Impedimenta, 2010. Impreso. Pinos, Jaime. "Aprender a despertar. Epílogo". Space Invaders.

Santiago: Alquimia editores, 2013. 83-88. Impreso.

Poblete, Nicolás. "El daño irreversible. Reseña: Nona Fernández".

Revista 60 watts. Web. 20 de diciembre de 2013.

Salinas, Rodrigo. Arturo Prat is not dead, Los viajes de Massachusetts.

La calma después de la tormenta. Calm Before the Storm.

Santiago: La Nueva Gráfica chilena, 2005. Impreso.

Sater, William. La imagen heroica en Chile. Arturo Prat, un santo secular.

Santiago: Centro de Estudios Bicentenario, 2005. Impreso.

Schwab, Gabriele. "Introduction". Haunting legacies. Violent

Histories and Transgenerational Trauma. New York:

Columbia University Press, 2010. 1-40. Impreso.

Spiegelman, Art. Mauss. A Survivor's Tale. New York: Pantheon Books, 1986. Impreso.

Young, James. "At Memory's Edge After-Images of the Holocaust in Contemporary

Art and Architecture. Art Spiegelman's Maus and the After-Images of History.

Chapter 1". Books. The New York Times on the Web. 2000. Web. Octubre de 2014. 